\title{
¿Cuál es su diagnóstico y tratamiento?
}

\section{What is the diagnosis and what is the treatment?}

Paciente de 67 años de edad, que refiere historia de cefalea punzante con maniobras de Valsalva de un mes de evolución, dolor ocular derecho con enrojecimiento y diplopia intermitente. En los últimos 10 días, la evolución es hacia un exoftalmos progresivo del ojo derecho y diplopia de carácter persistente. Los antecedentes personales no son importantes para el caso.

A la exploración oftalmológica presenta una presión intraocular de $24 \mathrm{~mm}$ de mercurio (PIO normal de 12 a $22 \mathrm{~mm}$ de mercurio), diplopia a la elevación vertical y dilatación venosa temporal y nasal, con discreto borramiento nasal de la

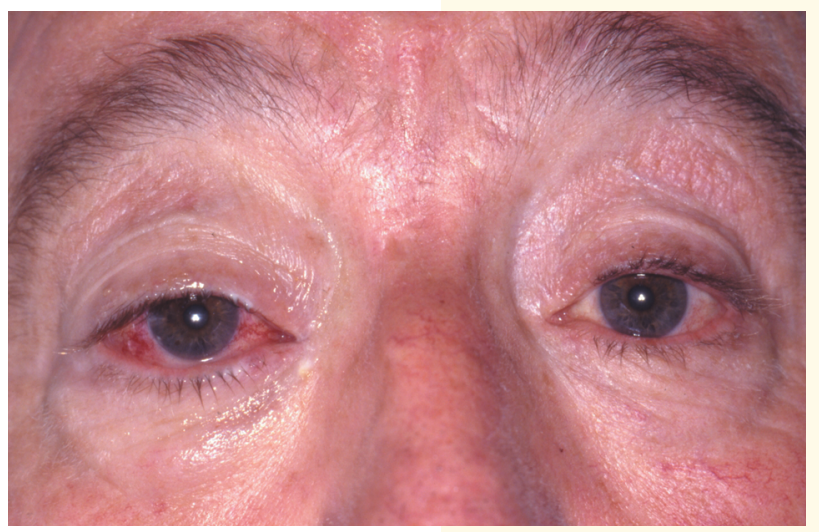

Figura 1. Imagen del paciente en el momento de su primera visita.

Figure 1. Image of the patient on first visit.
A 67-year-old patient reported a one-month history of shooting headaches with Valsalva maneuvers, ocular pain and redness on the right side and intermittent diplopia. Over the previous ten days progressive exophthalmos of the right eye and a persistent type of diplopia had developed. His personal history was not of relevance to the case.

The ophthalmologic examination revealed an intraocular pressure of $24 \mathrm{~mm}$ mercury (normal IOP is 12 to 22 papila.

Se solicita TC urgente, observando una tumoración intraorbitaria y extraconal en ángulo supero-externo de órbita derecha, de $1 \mathrm{~cm}$ de diámetro, que desplaza inferomedial el globo ocular. La musculatura intrínseca y las estructuras óseas son de características normales. Es ingresado para estudio, pautando tratamiento antibiótico y corticoideo y curas oclusivas del ojo con pomada epitelizante (Fig. 1). $\mathrm{mm}$ mercury), diplopia on upgaze and venous dilation in the temple and nasal [regions], with a certain blurring on the nasal of the papilla.

An emergency CT scan was requested, and an intraorbital extraconal tumor was observed at a supero-external angle of the right orbit, with a diameter of $1 \mathrm{~cm}$, that was displacing the ocular globe medially and downwards. The intrinsic musculature and bony structures appeared normal. He was admitted for further tests. Antibiotics and corticoid treatment was given together with ocular treatment consisting of epithelium ointment (Fig. 1). 


\section{Fístula carótido-cavernosa}

\section{Carotid-cavernous fistula}

\section{A. Riaño Argüelles', M.A. Bada García, C. Sebastián López1, J. Garatea Crelgo²}

Durante el ingreso hospitalario se realiza una ecografía orbitaria, en la que se aprecia un anormal calibre de la vena oftálmica superior, que presenta flujo conservado, planteando la sospecha de fístula carótido-cavernosa (Fig. 2).

El Servicio de Radiología nos recomienda ampliar el estudio con TC de senos cavernosos con contraste iv, que confirma la ingurgitación de la vena oftálmica, así como un agrandamiento del seno cavernoso derecho.

Se le realiza angiografía diagnóstica, mediante la técnica de Seldinger habitual, en la que se aprecia fistula carótido-cavernosa de bajo flujo, irrigada desde ambos lados, con aporte fundamental desde la arteria faríngea ascendente derecha y drenaje por vena oftálmica derecha (Fig. 3).

Se comenta el caso con el Servicio de Neurocirugía y se decide un tratamiento conservador del cuadro, con masajes aplicados por el propio paciente a nivel de la carótida derecha, de tres minutos de duración, tres veces por la mañana y tres por la tarde y seguimiento ambulatorio.

Al mes el exoftalmos y la diplopia habían cedido. Se le pide angioresonancia cerebral de control, habiendo desaparecido la fís-

\footnotetext{
1 Médico Residente.

2 Cirujano Adjunto.

Servicio de Cirugía Oral y Maxilofacial

Hospital Virgen del Camino. Pamplona, España

Correspondencia:

Ana Riaño Argüelles

Plaza Rafael Alberti n우 1으

31010 Barañain. Navarra, España
}

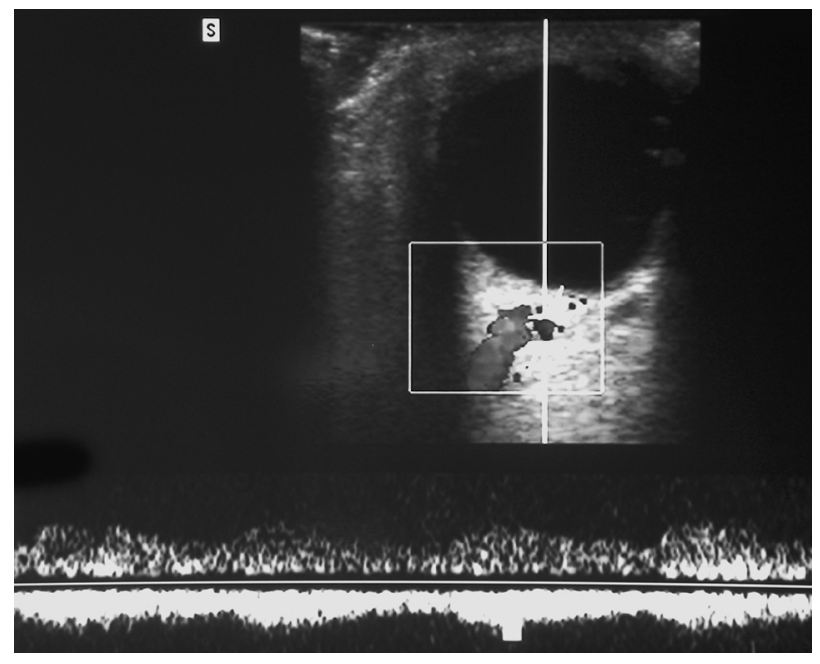

Figura 2. Detalle de la Eco-doppler orbitaria realizada. En ella se observa el shunt que se establece entre el flujo arterial y el venoso. Figure 2. Detail of the orbital echo-doppler carried out. The shunt between the arterial and venous flow can be appreciated.
During his hospital stay an echography of the orbit was carried out, in which the abnormal size of the superior ophthalmic vein could be appreciated. It had a lowflow and a carotid-cavernous fistula was suspected (Fig. 2). The Department of Radiology recommended further study with a CT scan of the cavernous sinuses with i.v. contrast. This confirmed the engorgement of the ophthalmic vein, as well as an enlargement of the right cavernous sinus.

A diagnostic angiography was carried out using the Seldinger technique that revealed a low-flow cavernous-carotid fistula, with shunting from both sides. It was supplied mainly by the ascending pharyngeal artery and drainage was via the right ophthalmic vein (Fig. 3).

The case was discussed with the Neurosurgery Department and, given the various symptoms, conservative treatment was decided on, with the patient himself massaging the right carotid for three minutes three times during the morning and three times in the afternoon with an outpatient follow-up.

A month later the exophthalmos and the diplopia had receded and an angioresonance check of the brain was carried out. The fistula had disappeared and an ophthalmic vein with a normal diameter was observed. The patient was discharged. 
tula y presentando una vena oftálmica de calibre normal. El paciente es dado de alta.

Las fístulas carótido-cavernosas son comunicaciones anómalas que se establecen entre la arteria carótida y el seno cavernoso, bien directamente o bien por ramas intradurales de las arterias carótida interna o externa. Pueden ser de origen espontáneo (congénitas, degenerativas, infecciosas) o traumáticas (3/4 partes). ${ }^{8}$

Barrow y cols. ${ }^{3}$ clasifican las mismas según los hallazgos angiográficos en dos grupos: fístulas carótido-cavernosas directas o tipo A y las indirectas o durales (tipo B-C-D)

Las fístulas "directas" se producen por la ruptura de la arteria carótida interna en el interior del seno cavernoso. Son de alto flujo, presentan un debut clínico dramático y se producen frecuentemente tras un traumatismo o por una ruptura aneurismática de la misma. Se han descrito

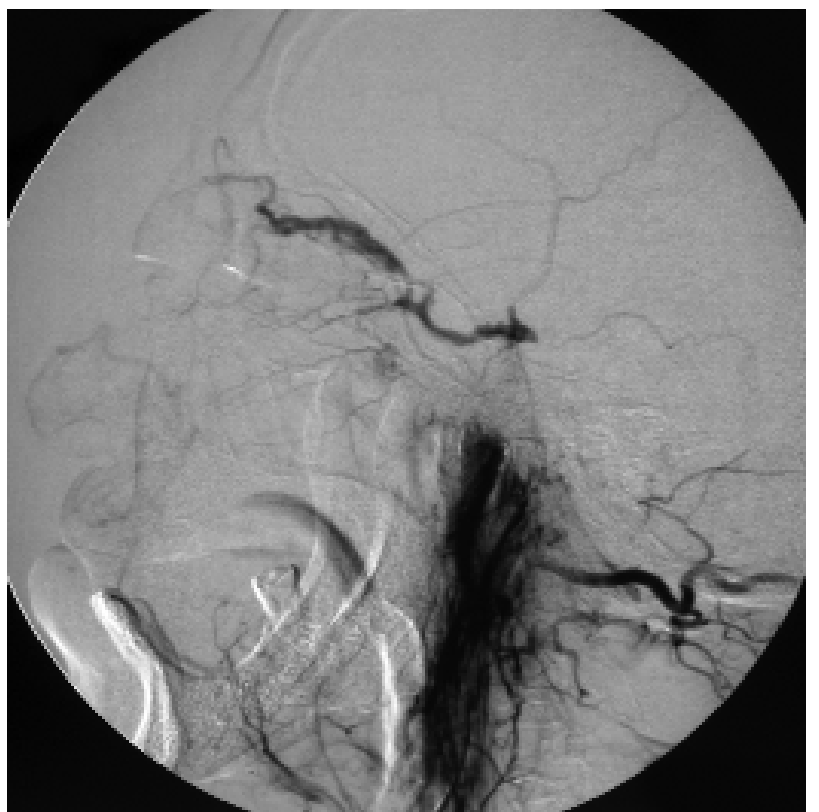

Figura 3. Imagen angiográfica: fistula de bajo flujo irrigada desde ambos lados.

Figure 3. Angiographic image: low-flow fistula with shunting from both sides.
Carotid-cavernous fistulas are anomalous communications that arise between the carotid artery and the cavernous sinus, either directly or through the intradural branches of the internal or external carotid arteries. They can be spontaneous (congenital, degenerative, infectious) or traumatic (three quarters). 8 Barrow et al. ${ }^{3}$ classified them according to angiographic findings into two groups: Direct or type A carotid-cavernous fistulas, and the indirect or dural (type B-C-D). The "direct" fistulas are produced as a result of a rupture of the internal carotid artery within the cavernous sinus. There is a high-flow, and the clinical onset is dramatic. They often occur following trauma or because of the rupture of an aneurysm. Cases have been described following a Le Fort I type osteotomy. ${ }^{2}$

Those with a low-flow, or that are "indirect", are produced through a generally spontaneous rupture of the smaller branches the internal or external carotid arteries and the cavernous sinus. They are clinically indolent, and they appear more frequently in perimenopausal women. They are attributed to a multiple of causes among which are congenital anomalies, spontaneous venous hypertension due to thrombosis, arteriosclerosis, collagen diseases, syphilitic arteritis and iatrogenic vascular injury.

These are divided into: type $B$ (meningeal branches of the internal carotid artery), type $C$ (meningeal branches of the external carotid artery) and type $D$ (branches of both arteries).

The new fistulous connection produces, in addition to the typical compressive symptoms of an "intraorbital mass", increased flow together and intracavernous pressure, together with a retrograde flow. This reverse flow leads to orbital venous hypertension and, as a result pulsating exophthalmos, chemosis, retinal venous congestion, headaches and orbital pain. A pathological sign is fronto-orbital whistling (tinnitus) in time with the pulse on lying down. There is an early onset of ptosis and diplopia, with the latter being the most common symptom, as the occulomotor muscles are compressed. How serious this is depends on the amount of fluid and the capacity for venous drainage.

The pattern of venous drainage frequently dictates the clinical findings and radiographic appearance. Although 
Como signos radiográficos de la fístula nos encontramos el aumento de dimensión de la vena orbitaria superior (no específico de fístula), abombamiento lateral del seno cavernoso, engrosamiento de los músculos extraoculares y un flujo en el seno cavernoso anormal.

Cuando existe ausencia de drenaje anterior o de aumento de la vena oftálmica superior, es fundamental realizar una angioresonancia magnética con gadolinio. Si existe fístula se observa una imagen hiperintensa en el seno, que corresponde a un fístula carótidocavernosa con una sensibilidad del $83 \%$ y una especificidad del $100 \% .^{1}$ Sin embargo, esta técnica no puede definir cuales son las arterias implicadas en la fístula ni el drenaje venoso cortical, para lo que sería necesaria una angiografía convencional.

El diagnóstico diferencial hay que realizarlo con numerosos procesos capaces de provocar desplazamiento del globo: tumores benignos (hemangiomas, quistes dermoides y epidermoides, mucoceles frontoetmoidales, tumores de glándula lagrimal), malignos (tumores de glándula lagrimal; leucemias y linfomas; metástasis principalmente de mama, pulmón, melanoma maligno, carcinoma gástrico, el carcinoma genitourinario; rabdomiosarcoma, glioma del nervio óptico o astrocitoma pilocítico juvenil), oftalmopatía tiroidea, infecciones (celulitis orbitaria, pansinusitis), hemorragias retrobulbares secundarias a traumatismos, vasculitis orbitaria (granulomatosis de Wegener, PAN), sarcoidosis, etc.

El primer tratamiento exitoso de este cuadro fue realizado por el cirujano británico Travers, y consistía en ligar la arteria carótida común, desde entonces, los avances terapéuticos han sido cuantiosos. El tratamiento debe ser urgente,,$^{6,7}$ cuando provoque hipertensión intracraneal, déficits neurológicos, pérdida de visión, accidentes isquémicos transitorios, etc, La actitud terapéutica varía según el tipo de fístula ante la que nos hallemos:

- Fístula "directa" o de alto flujo: embolización de la arteria mediante un balón endovascular o mediante partículas.

- Fístula "indirecta": no es posible el tratamiento anterior porque reciben múltiples y diminutas suplencias arteriales de la arteria carótida interna o externa. Si los síntomas son estables, se tiende a la observación. Un $30 \%$ de los casos se soluciona mediante maniobras de compresión con una pauta horaria reglada, como el caso que nos ocupa. No obstante, conviene seguirlas de cerca, porque pueden producir un rápido deterioro de la visión o de la función de los nervios craneales, como consecuencia de un aumento de la presión intraocular por retorno venoso retrógrado a través de la vena oftálmica superior. En las venas de la carótida externa (tipo C) el abordaje es a través del seno cavernoso, embolizando las ramas de la arteria carótida externa con alcohol polivinílico y colocando, distalmente al lugar de la inyección, un balón endovascular para lograr un daño vascular selectivo, sin migración del alcohol por el vaso. Este tipo de abordaje sería imposible de realizar, si se demuestran evidencias angiográficas de un seno petroso inferior o gran angulación de la vena oftálmica superior, por el alto riesgo de perforación iatrogénica y de hemorragia retroorbitaria. Se consigue por esta técnica una rápida mejoría de la pérdida de agudeza visual, de la movilidad extraocular y un descenso significativo de la presión intraocular. anterior drainage into the sinus and ophthalmic veins produces the most ocular symptomatology and a greater lengthening of the superior orbital vein, it takes longer to detect using $C T$ and $M R$.

An echography is crucial for pin-pointing this pathology as the cause of this group of symptoms and not any other within the "orbital masses" group. An arterialized flow, reversed into the superior ophthalmic vein can be observed.

Radiographic findings of the fistula will show an increase in the size of the superior orbital vein (that is not specific to the fistula), lateral bulging of the cavernous sinus, enlargement of the extraocular muscles, and an abnormal flow in the cavernous sinus.

Performing gadolinium magnetic resonance angiography is of fundamental importance if there is no anterior drainage nor an enlargement of the superior ophthalmic vein. If there is a fistula, a hyperintense image will be observed in the sinus, which would correspond to a carotid-cavernous fistula with a sensitivity of $83 \%$ and specificity of $100 \% .1$ However, this technique is not able to distinguish between the arteries implied in neither the fistula nor the cortical venous drainage, and for this a normal angiography would be necessary.

The differential diagnosis should be made using various procedures capable of producing the displacement of the globe: benign tumors (hemangiomas, dermoid and epidermoid cysts, frontoethmoidal mucoceles, lacrimal gland tumors), malignant (tumors of the lacrimal gland; leukemias and lymphomas; metastasis principally of the breast, lungs, malignant melanoma, gastric carcinoma, genitourinary carcinoma; rhabdomyosarcoma, glioma of the optic nerve or juvenile pilocytic astrocytoma), thyroid ophthalmopathy, infections (orbital cellulitis, pansinusitis), retrobulbar hemorrhages secondary to trauma, orbital vasculitis (Wegener's granulomatosis, PAN), sarcoidosis, etc.

The first successful treatment with this group of symptoms was carried out by the British surgeon Travers, and it consisted in ligating the common carotid artery, and since then therapeutic advances have been plentiful. When there is intracranial hypertension, neurologic deficits, loss of vision, transitory ischemic attacks etc treatment should be given urgently. 6,7 The therapeutic approach varies depending on the type of fistula we are dealing with.

A "direct fistula" or one with a high-flow: embolization of the artery by means of an endovascular balloon or particles.

An "indirect" fistula: The previous treatment is not possible because a multiple of tiny arterial feeders are received from the internal or external carotid arteries. If the symptoms are stable, there is an inclination towards observation. $30 \%$ of cases are solved by means of manual compression at regular intervals, as in the case we are dealing with. Nevertheless, this should be supervised closely, because there can be a rapid deterioration in vision or in the function of the cranial nerves, as a consequence of an increase in intraocular pressure caused by retrograde venous flow through the 
En los tipos D solo se embolizan las ramas de la carótida externa, dada la dificultad que estriba el cateterizar las finísimas ramas de la carótida interna, sin miedo de la irrupción de los agentes esclerosantes en el interior del seno cavernoso.

Finalmente, en aquellos pacientes en los que se observe flujo residual y resolución incompleta de los síntomas se plantea ya la radiocirugía estereotáxica.

\section{Bibliografía}

1. Rucker JC, Biousse V, Newmann NJ. Magnetic resonance angiography source images in carotid cabernous fistulas. Br J Ophthalmol 2004;88:311.

2. Precious David S. Management of complications of maxillary osteotomies. J Oral Maxillofac Surg Online Septiembre, 2004.

3. Koebbe C), Horowitz M, Jungreis C. Alcohol embolization of carotid-cavernous indirect fistulae. Neurosurgery Online 2003;52:1111.

4. Rhee D], Pyfer MF. Manual de Urgencias Oftalmológicas. 3를 ed. McGraw-Hill Interamericana Nov 2000, p.p. 181-205.

5. Villacampa T. Oftalmología. Curso MIR ASTURIAS 2002, p.p. 111-118.

6. Chaloupka JC, Putman CM. Endovascular therapy for surgical diseases of the cranial base. Clin Plast Surg 1985;77:981.

7. Halbach W, Hieshima GB, Higashida RT, y cols. Carotid-cavernous fistula: indications for urgent treatment. AJNR 1987;8:627-33.

8. Albertos JM, Junquera LM, Diego J, Villarreal P. Fístula carótido-cavernosa asociada a una fractura mandibular. Rev Esp Cir Oral Maxilofac 1997;19:145-50. superior ophthalmic vein. For the external carotid veins (type C) the approach is through the cavernous sinus, and the branches of the external carotid artery are embolized with polyvinyl alcohol and an endovascular balloon is placed distally at the point of entry, so that there is selective vascular damage, with no migration of the alcohol along the vessel. This type of approach would be impossible to carry out if there was angiographic evidence of an inferior petrosal sinus or if the superior ophthalmologic vein had a sharp bend, because of the high risk of iatrogenic perforation and retroorbital hemorrhaging. With this technique a rapid improvement is achieved in vision acuity, extraocular mobility and there is a significant descent in intraocular pressure.

In the D types only the branches of the external carotid are embolized, given the difficulty of cauterizing the very fine branches of the internal carotid, for fear of introducing the sclerosing agents in the interior of the cavernous sinus.

Finally, in those patients in whom residual fluid has been observed and with symptoms that have not been completely resolved, stereotactic radiosurgery should be considered. 